
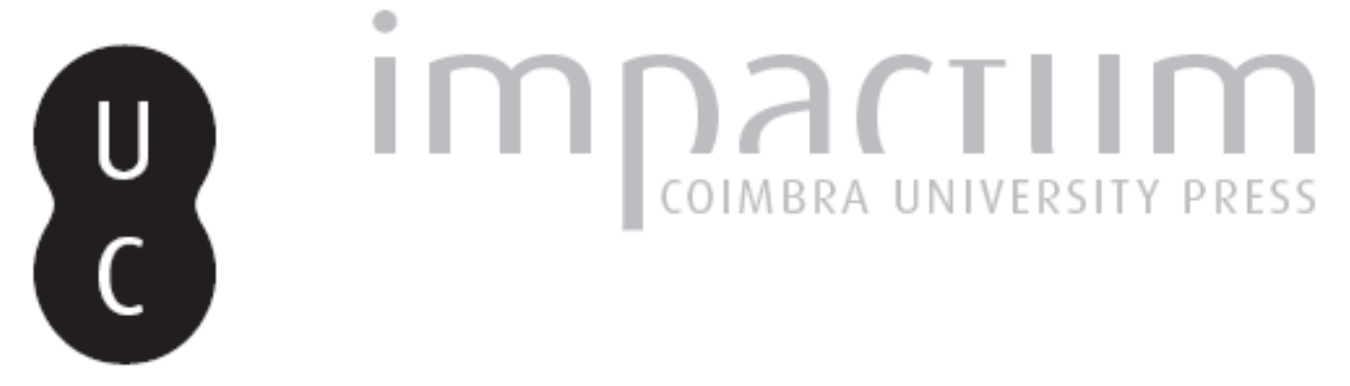

Reconstructing journalism ethics: disrupt, invent, collaborate

Autor(es): Ward, Stephen J. A.

Publicado por: Imprensa da Universidade de Coimbra

URL persistente:

URI:http://hdl.handle.net/10316.2/43893

DOI:

DOI:https://doi.org/10.14195/2183-5462_32_1

Accessed : $\quad$ 26-Apr-2023 01:57:42

A navegação consulta e descarregamento dos títulos inseridos nas Bibliotecas Digitais UC Digitalis, UC Pombalina e UC Impactum, pressupõem a aceitação plena e sem reservas dos Termos e Condições de Uso destas Bibliotecas Digitais, disponíveis em https://digitalis.uc.pt/pt-pt/termos.

Conforme exposto nos referidos Termos e Condições de Uso, o descarregamento de títulos de acesso restrito requer uma licença válida de autorização devendo o utilizador aceder ao(s) documento(s) a partir de um endereço de IP da instituição detentora da supramencionada licença.

Ao utilizador é apenas permitido o descarregamento para uso pessoal, pelo que o emprego do(s) título(s) descarregado(s) para outro fim, designadamente comercial, carece de autorização do respetivo autor ou editor da obra.

Na medida em que todas as obras da UC Digitalis se encontram protegidas pelo Código do Direito de Autor e Direitos Conexos e demais legislação aplicável, toda a cópia, parcial ou total, deste documento, nos casos em que é legalmente admitida, deverá conter ou fazer-se acompanhar por este aviso.

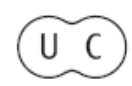




\section{Mediasornalismo}

ÉTICA JORNALÍSTICA PARA O SÉCULO XXI NOVOS DESAFIOS, VELHOS PROBLEMAS

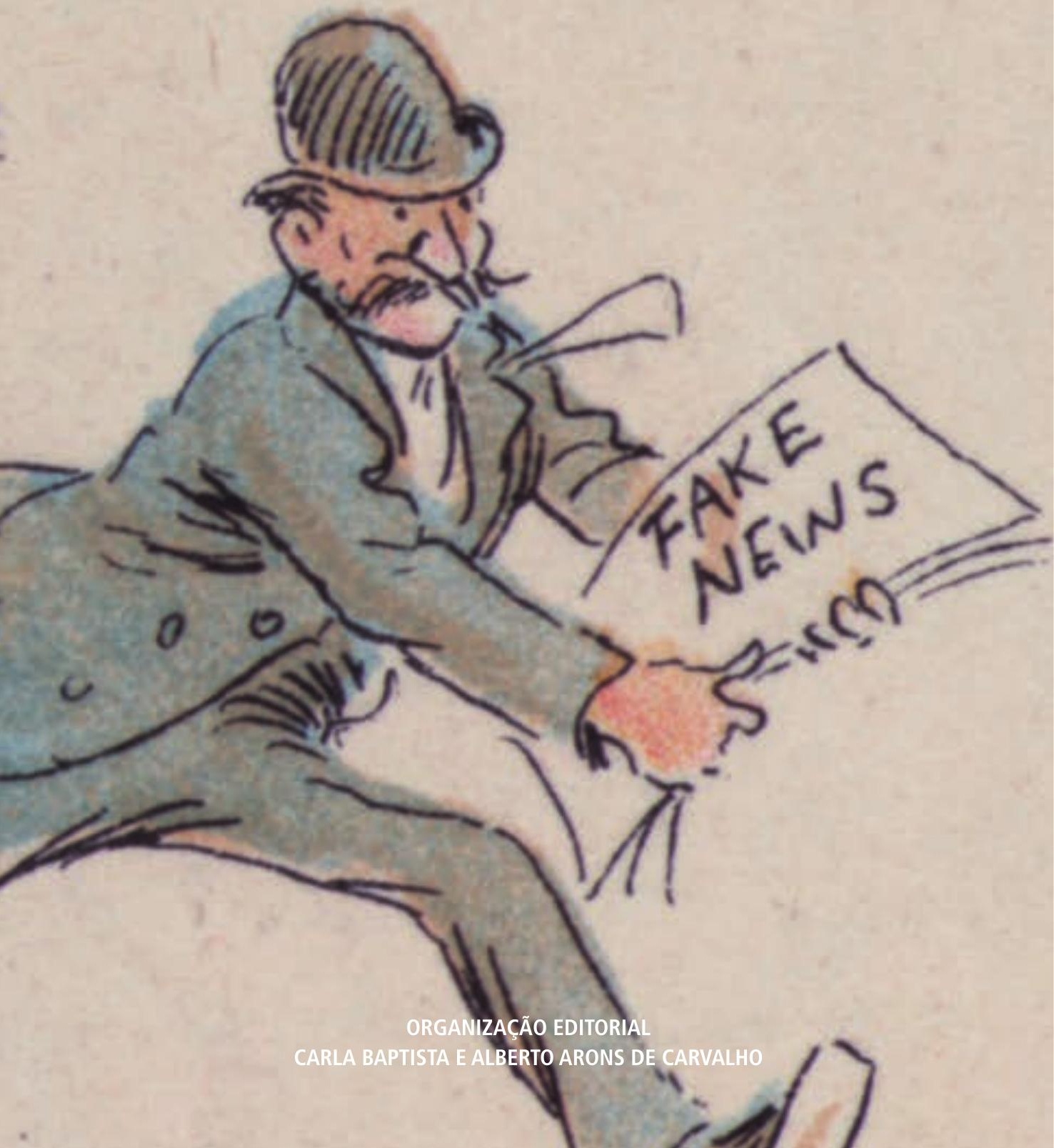




\title{
RECONSTRUCTING JOURNALISM ETHICS: DISRUPT, INVENT, COLLABORATE ${ }^{1}$
}

\author{
STEPHEN J. A. WARD \\ University of British Columbia. Vancouver, BC Canada V6T $1 Z 4$ \\ stephen.ward@bellaliant.net
}

\section{Artigo por convite /Article by invitation/Artículo por invitación}

Journalism ethics is not difficult to define: It is the study and application of norms that guide the practice of journalism, in its many forms. Yet this bland statement conceals the tumult that surrounds journalism and its ethics. Journalism ethics today is a problem, not only a set of standards.

The problem is disagreement on fundamental principles. What norms can regulate a journalism that is digital and global, practiced by professional and citizen? How maintain journalism's integrity amid a universe of media shaped as much by partisans as by fact-checking professionals? Journalism ethics has a deep identity crisis. Barely a principle or practice goes unchallenged. Journalism ethics resembles a fragmented archipelago of conflicting views. We witness the decline of a tidy, pre-digital, parochial ethic for professionals and the emergence of an untidy ethic of digital, global media for almost anyone.

Take, for example, the failure of Facebook to prevent misinformation and fake news to overtake its news feed in the hours after the Las Vegas shooter went on his rampage. Despite months of promises to preclude misuse of its site, Facebook was full of right-wing sites, disguised as mainstream news, blaming the event on "lefties" nut cases; faulty algorithms that mixed serious news with news on bitcom and bloggers seeking to attract eyes to sell ads. As one writer for Buzzfeed concluded: "The Big Platforms Still Suck During Breaking News."

Given this tumult, detachment is not an option. We should respond to movements that threaten journalism. But how? It depends on the context.

Today, two macro trends drive our media revolution. One trend is the reshaping of the speed and nature of journalistic work by digital tools. The second trend is the digital reshaping of the public sphere into a raucous, global, space. Networks, ideologues, and NGOs use media to inform, advocate, troll, share, and engage in propaganda. The professional journalist and her ethics play a diminished role.

Compare the issues that have preoccupied journalism with the issues today. The problem for professional ethics, constructed in the early 1900s, was how to act in specific situations according to principles of objectivity, truth-telling, and independence. News would be separated from opinion. In North America and elsewhere, the ideal reporter was a neutral stenographer of fact. Journalism ethics was taught in

1 Lecture presented at the Conference Journalism Ethics for the 21st Century, University Nova, Lisbon, Oct. 12, 2017 
a static manner, as the application of invariant principle in a stable public sphere to recurring problems, e.g., granting anonymity to a source.

Now, consider some issues within journalism today:

Issues of identity. If citizens report, who is a journalist?

Issues of scope: If everyone's a publisher, does ethics apply to everyone?

Issues of principle: What are the appropriate principles?

Issues of new practices: How can new practice, e.g., entrepreneurial journalism, maintain editorial independence?

Issues of participation: What norms guide the news media's use of information and images provided by citizens? How should news outlets partner with civil society groups, government, and media funders?

Now consider some issues in the public sphere:

Issues of corruption: If the public sphere is redolent with manipulative voices beyond effective control, whither journalism ethics?

Issues of stance: Where facts and truth are in jeopardy, should journalists be neutral or engaged?

Issues of ideology: How can journalism serve a public divided into ideological camps?

Issues of amplification: How report hate speech without giving groups the publicity they seek?

Issues of global media: How should codes change to guide stories with global impact?

Issues of mind warfare: What role for journalism if secretive agencies use media to undermine elections, to hack, and to sway opinion?

The difference between the old and new issues is not that traditional concerns, e.g., the use of anonymous sources, have disappeared. They have not. The difference is otherwise, in three ways: One, traditional discussions presumed agreement on principles to adjudicate issues.

That consensus no longer exists. Two, even where the issue is the same, e.g., verifying stories, the problems are different. Verification in a digital world of instant "sharing" of information is vastly more difficult than the traditional and, by comparison, 'leisurely' pace of verifying stories for tomorrow's printed newspaper. Third, current questions go deeper to the nature of journalism, and the conditions of democracy.

Given this context, our intervention should be disruptive and radical. We disrupt entrenched ways of thinking inherited from journalism, ages ago. We reformulate fundamental principles. We identify norms that apply across media platforms and borders. We should disrupt, invent and collaborate.

\section{Invent: A Mindset}

But how invent? We begin by changing how we think about ethics. We need a mindset conducive to change. I propose a mindset with four ideas: (1) journalism 
as objective engagement; (2) journalism ethics as dialogic; (3) journalism norms as fallible and emergent; and (4) journalism ethics as global. Let me briefly explore each idea.

\section{Objective Engagement}

To face a troubled public sphere, journalists could 'double down' on traditional values of reporting just the facts. Or, journalists could become partisan activists. I believe both options are mistaken. If journalists join the protesters, it will erode media credibility and contribute to an already partisan-soaked media sphere. Yet a journalism of 'just the facts' is too passive and ripe for manipulation. What is a fact is up for debate, and requires active investigation. I propose we think of journalism as lying between partisan advocacy and mincing neutrality. Journalists are not neutral, in the sense of having no goals or perspectives. They are engaged interpreters. Competitions for journalism awards and many codes of ethics appeal to the social goals of journalism: to serve a public, to give voice to the powerless, to reveal wrong-doing and injustice. So, the real question is how to test interpretations and what goals journalists should have. In my view, the ultimate goal is to protect and advance plural, egalitarian democracy, globally, for the sake of human flourishing and social justice.

We need an ethic for a democratically engaged journalism that is both impartial and engaged. Partial in favoring democratic goals but impartial in method, in how we approach stories.

\section{Dialogic Journalism}

Now, if reconstruction is the pressing issue, then discourse is crucial. We need to think of journalism ethics as not simply "content", i.e., a fixed set of norms. We need to think of journalism ethics as open-ended discourse on an ethics-to-be. Ethics is a process of deliberation aimed at articulating new norms for diverse kinds of journalists. For the foreseeable future, journalism ethics will be discursive. It should also be dialogic. Journalism should encourage dialogue about itself. To be a journalism ethic that crosses platforms and borders, we need to seek common ground while recognizing local difference. Moreover, news organizations should create dialogic forms of programs and online discussions. That is, develop public channels that promote reasoned debate rather than partisan ranting. Democracy is civic participation in defining the common good through an exchange where participants listen and learn. Democracy requires more than having many voices online. How the voices communicate and interact is equally important. Dialogue opens up journalism to a rich manifold of new perspectives.

\section{Imperfectionism}

Now, this mindset presumes an epistemology of ethics. How do we justify and change our ethical beliefs and practices? The epistemology we need to effect change is not a dogmatic epistemology that regards ethics as universal principles known with certainty. In this view, ethics is a house that withstands change by standing on a foundation of absolute principles. Rather, we need an epistemology that I call "imperfectionism." It regards ethics as the imperfect, situated attempt to fairly re- 
solve problems of social cooperation. Ethical rules are proposals for rules of conduct. There are no sure foundations. This view of ethics opens us up to listening and learning, opens up a space for invention. We experiment. We pioneer. We regard disagreement as an essential and often positive aspect of ethics. In changing times, we expect ethics to be an area of emergent and contested belief. Journalism ethics today is a prime example of emergent ethics. A zone of contestation between new and old values.

\section{Global Ethics for Everyone}

Finally, we need a global mindset. Journalists should 'globalize' their self-understanding and their codes of practice. Journalists should go beyond the parochial view that they serve primarily their group or country. They should take as their ultimate aim that of serving humanity. Journalists should make global justice and human rights their fundamental values. This means a lesser role for patriotism, especially strong nationalism, let alone "America First" attitudes.

\section{Implement and Collaborate}

Suppose we agree on this mindset, how would we implement it in practice? Here are some practical things we might do, with examples.

Within journalism, we should improve the "material" conditions of independent journalism. As my work with journalists in Guatemala taught me, talk of ethics presupposes a media that is economically sufficient, politically independent, educated, and free from threats. Try talking ethics to a journalist who needs bribes to feed his family.

We need to strengthen global networks to provide financial, educational, legal and other forms of media development. Among the material conditions is media diversity - diversity in ownership and kinds of media, and diversity among journalists in newsrooms. Therefore, I favor support for public broadcasting, and incentives to create alternate media. We also need engaged forms of local, community reporting-journalism that comes out of community.

Another area is attention to norm development. It is a stool with three legs: norm invention, accountability, and transparency. In all three areas we need a "public revolution" - the participation of publics. Rather than talk of media "self-regulation" perhaps we should think about public-regulation, or public-directed ethics. Rather than ask what journalists need, ask what the public needs from its news media. What I learned from serving on code committees is that no news organization should revise their code without giving citizens a central place in the whole process - not just asking for feedback to a code after it has been drafted in-house by a professional committee.

Moreover, codes should be dynamic, interactive, and useful. Principles and practical guidelines are interwoven. Instead of being a list of abstract principles, codes should be living documents with links to sections on new practices, controversial issues; plus guidelines for new technology such as use of drones and virtual reality; plus best practices for vetting information from citizens. Rather than being 'ethical eye candy' tacked to a wall or web site, codes should be used daily in decisions and improved through public discussion. They should articulate 
values for both staff and public, and they should be the basis for accountability mechanisms in newsrooms.

Today, there is much writing and revising of codes, from the BBC to the Society of Professional Journalists in the USA. The Canadian Association of Journalists develop guidelines for issues such as picking up stories from social media. Also, there is a global media ethics movement that meets globally and publishes advice on covering global issues. Some, like myself, have written a global code for journalism http://mediamorals.org/introducing-the-ward-code-for-global-integrated-ethics. New books on reporting on human rights are being published, as shown on the slide. The Ethical Journalists Network in London is developing norms and practices for covering terrorism, hate speech, and immigrants http://ethicaljournalismnetwork. org/en. In Australia, a university group works on reporting Islam. In addition, we need norms for new experiments in journalism. For example, I co-directed a project to write guidelines for non-profit journalism in the United States, where financial conflicts-of-interest are intense.

So, overall, what should a future journalism ethics look like in terms of new norms and content?

Ethics of new media ecologies \& new media: Guides for new practices in new forms of journalism.

Ethics of interpretation, opinion, and activism: Journalism will continue to become more interpretive and engaged. We need deep discussions of what norms can guide such writing.

Ethics of global democratic journalism: We need to develop a global media ethic.

But norm articulation is not enough. We need effective means of media accountability. With digital journalism, accountability is a vexed issue. In North America, existing means of accountability, e.g., news councils and ombudsmen, grow weak. Councils are few in number, unknown or unused by the public and mainly "complaint" centers. They are too often seen as an arm of industry, to avoid law suits. We should be able to set up online accountability platforms that mix citizens and professionals, that do more than take complaints, and are pro-active in spreading public knowledge of media issues. But old models persist. In Canada, a new national media council is essentially the same in structure as the councils set up in the 1980s. Yet, even if we reform traditional structures, we face the problem of how to hold accountable online voices that propagate hate, abuse individuals, or falsely accuse people of crime. But what mechanisms are possible? I am not sure, frankly. Meanwhile, transparency of editorial process is important, such as the "Backstory" feature at Reuters http://www.reuters.com/backstory. However, I do not join those who think transparency is a magical "fixer" of all things wrong with journalism. It is one tool among many.

These practical issues have large implications for the education of journalists and citizens.

We should teach journalism ethics not as a canon of doctrine but as a way of thinking where students define their own framework and understand the transition 
to a new media ecology. We need research that breaks down the dualism of practice and theory. One example is The Worlds of Journalism project that rethink how journalists fits into society and what values unite journalists across borders http:// www.worldsofjournalism.org/.

Also, we need educational resources for journalists in the field, in real time. For example, the Harvard's Shorenstein Center puts out a weekly list of top research articles for journalists to consult on breaking issues https://journalistsresource.org/. Why not have a global version of such?

Journalism schools need to get closer to the social sciences and cultural studies. They should be linked to disciplines that deal with our global world, such as centers of international communication, the study of global democracy, the anthropological study of other cultures, and the comparative study of religion. Many journalism programs focus on new technology, from data analysis to virtual reality, but such skills should be enriched by a knowledge of the world. Journalists must be interpreters of culture, deeply aware of their world, its history and philosophies.

For example, Oxford University and University of Cape Town have developed a Master's degree in global journalism. Students spend half their time in London and half in Cape Town, and write about the similarities and differences in media and culture. At University of British Columbia's School of Journalism they have a global reporting center that takes senior students each year to foreign countries to write a series on some global issue, such as the treatment of mental illness in India. Prior to the trip, the students spend a term learning about the cultures they will be visiting. Academics, and people who live in these countries, help the students understand the issues http://globalreportingcentre.org/.

However, education does not stop with the working world of journalists. We should teach both media ethics and media literacy early in public education, and across faculties in universities. We should end the segregation of media ethics in schools of journalism. Also, we need a broad public discussion on media ethics for citizens-norms for using media that go beyond journalism to such problems as cyberbullying.

Meanwhile, how do we find the resources to do important journalism in an era of shrinking budgets?

In the USA alone, newsrooms have lost 28,000 jobs. One response is collaboration among journalists. The best-known example was the Panama Papers project where hundreds of journalists worked on offshore financing. Similar global networks are forming among non-profit news sites and other places. Collaboration is a popular theme. Another response is to support single-topic news sites such as sites that deal with immigrants, police abuse etc. A recent example of collaboration in Canada was an investigation into the harmful effects of hydrogen sulphide, leaking from shale oil wells across Saskatchewan. The investigation discovered oil company violations and dangerous air quality levels kept secret by government. It was conducted by three rival news outlets, such as the Toronto Star, and four journalism schools. www.thestar.com/news/canada/2017/10/01/that-rotten-stench-inthe-air-its-the-smell-of-deadly-gas-and-secrecy.html

Now, how about media issues in society, such as fake news?

One response is collaboration in fact-checking of events and claims. Fact check- 
ing has become a virtual industry. Recently, the Knight Foundation in the USA gave $\$ 4.5$ million to projects to expose unreliable media work.

At the University of Missouri, the media trust project is studying why people trust certain media formats https://www.rjionline.org/stories/series/trusting-news. The Shorenstein Center announced that First Draft, the coalition against fake news is moving into the center. First Draft has helped coalitions fact-check elections in France and elsewhere https://shorensteincenter.org/first-draft-joins-shorenstein-center/.

There is much happening in this area. Here are a few headlines from the USA alone, in recent weeks.

- University of Arizona's Cronkite Journalism School partners with Facebook to study ways for people to engage the news.

- Three philanthropic organizations will make $\$ 3$ million available to over 100 non-profit news outlets to do investigative journalism and community news.

- The Challenge Fund, which challenges universities to teach journalism differently, announces $\$ 1$ million in "micro-grants" to 10 universities to partner with news organizations to do local community news, from creating student news services to inform rural areas, to trust-building news for immigrant audiences.

Another response is to talk about civic engagement in journalism, where journalists get closer to their communities. Engagement is the defining concept of the Agora Center for Journalism at the University of Oregon. The aim is to locate journalism within community http://journalism.uoregon.edu/agora/.

Yet with partnerships come ethical issues. Government, civic societies, journalists and universities find themselves in the same bed, talking about education in digital media. For example, the Canadian government announced a partnership with Netflix to spend $\$ 500$ million to create new Canadian content in film and elsewhere. Facebook has a Journalism Project to create closer ties to the news industry and educators. The Ryerson Journalism School in Toronto will use Facebook funds to launch an "incubator" for new ideas on digital journalism and engaging audiences. The initiative was announced by the federal government who is looking for other "interventions" to promote innovation.

Meanwhile, Google Canada is working with civic and government partners to invest $\$ 500,000$ to teach five-million elementary and high school students to be news literate. While the partnerships appear benevolent and the funding is needed badly, ethical concerns about the independence of journalism instruction, research, and publication should not be dismissed. Agreements to partner need explicit conflictof-interest clauses and such measures should be made public. We should not be naïve: Google, Facebook — the "press barons" of today—are not doing this simply out of the goodness of their own heart.

Another response is to develop and teach new technology to verify stories and images. These new books and web sites are caught up in a journalistic "arms race" where journalists design new tools to respond to new weapons of misinformation.

So, we need to be critical about fact-checkers yet, overall, I applaud such movements. But, by itself, fact-checking is inadequate. Why? Because the public needs so 
many other things from media that accurate facts. It needs informed analysis, deep explanatory journalism, and journalists skilled in the interpretation of complex trends.

We need to know more than that a politician made a false statement, or a "pantson-fire" lie. We need to challenge questionable policy and the misinterpretation of basic political principles. Journalism should remind citizens about the very conditions of plural democracy, such as the value of tolerance, equality, minority rights, the separation of powers, and so on. These are crucial social and philosophical understandings that are skewed and simplified in the media.

Moreover, fact-checking presumes most citizens are open to all of the facts and reasonable dialogue about issues. But, what if many citizens, as in the United States, are so ideologically divided that they will not listen to facts? Or will listen only to facts that suit their aims and originate from like-minded news outlets? What if tomorrow the New York Times published true stories of importance about the Trump presidency and a substantial number of Americans ignore it because it was issued by 'liberal' media? Here the problem is larger than getting the facts right, or revealing false facts. It is a social problem beyond journalism.

The issue is how to deal with the deep divides among us, how to reduce the attraction of fierce ideologies, how to inform people who may be likely recruits for extreme groups. So, we need broad social initiatives to address media literacy and to reduce ideology and hatred. Here, the journalist's role is not just one of fact-checker but of being a bridge of understanding among cultures and ethnic groups.

\section{Macro-Resistance}

What all of our efforts to improve media should amount to is a "macro-resistance" to negative media forces. Negative macro trends can only be balanced by positive macro resistance. Do not be despondent. We can work together to preserve, at the heart of our media systems, a core of responsible communicators-journalists and citizens. But such work will be demanding. It will require unprecedented collaboration among journalists, media centers, researchers and citizens.

In summary, journalism ethics needs a more complex, engaged ethics for a more complex world. My nervousness about the present is based on my experience as a war reporter.

I saw directly what extreme parochialism can do to otherwise civilized people. But the experiences that affected me most was seeing, first-hand, the savage cruelty of war. In the suffering of individuals, I saw the common humanity in all of us, and how fragile it is.

But you may ask: In the face of such practical problems, why do I stress mindsets, and ideas? Why hang on to notions of rationality and objectivity? Because in the end so much depends on how we think. The discipline of mind that these values call for is what lies between reason and unreason, between seeking evidence and wishful thinking; between being informed and simply having an opinion; between being open to revision and being dogmatically self-satisfied; between seeking dialogue and rejecting compromise as a weakness; between the hard road 
of constructing well-evidenced positions and the easy pleasures of ranting; between welcoming dissent and seeing people with different views as traitors; between communication aimed at richer understandings and communication aimed at victory through any means.

When we ask journalists to step back from their own beliefs, to verify claims, and to fairly represent viewpoints, we ask them to practice their craft in a manner essential to tolerant, plural democracies. And, now, such an attitude is essential to correcting a corrupted public sphere where it seems that the force of personality and intolerant certainty is all, an illusionary and machoistic sign of strength. If this mindset prevails, it will surely be the death of democracy and the rise of a new tyranny.

Stephen J.A. Ward - Distinguished Lecturer in Ethics; University of British Columbia-Vancouver; Editor-in-Chief, Handbook of Global Media Ethics; Founding Director, Center for Journalism Ethics; University of Wisconsin-Madison; Honorary Fellow, School of Journalism and Mass Communication; University of Wisconsin-Madison 